\title{
THE DEVELOPMENT OF ORO-ORO DOWO TRADITIONAL MARKET LOGISTICS IN THE NEW NORMAL ERA WITH JOINT DELIVERY APPROACH
}

\author{
Riza Nuansyah Putra ${ }^{1}$, Ismu Rini Dwi Ari ${ }^{2}$, Christia Meidiana ${ }^{3}$
}

Brawijaya University, Indonesia

Email: rizanuansyah@gmail.com, is_2mu@yahoo.com,ctiadiana@gmail.com

\begin{tabular}{|c|c|}
\hline ARTICLE INFO & ABSTRACT \\
\hline $\begin{array}{l}\text { Received: } \\
\text { January, 26 } \\
2022 \\
\text { Revised: } \\
\text { February, } 17^{\text {th }} \\
2022 \\
\text { Approved: } \\
\text { February, } 18^{\text {th }} \\
2022\end{array}$ & $\begin{array}{l}\text { The growth of electronic commerce is one of the challenges } \\
\text { for the development of urban logistics in Indonesia. This } \\
\text { condition was then exacerbated by the COVID-19 pandemic, } \\
\text { which forced changes to the social interaction system. In } \\
\text { Malang City in particular, there are regulations that make } \\
\text { traditional markets prioritize electronic purchasing systems. } \\
\text { Oro-oro Dowo Market is supported by } 4 \text { service developers } \\
\text { who support online transaction activities. Each } \\
\text { development has its own mechanism for the movement of } \\
\text { goods according to the characteristics of the service } \\
\text { developer. Using a qualitative descriptive method, it is } \\
\text { known that additional traditional market facilities are } \\
\text { needed to support these activities. The spatial arrangement } \\
\text { of the Oro-oro Dowo Market is an initial alternative for } \\
\text { developing a development strategy. Then the concept of } \\
\text { online traditional market interaction patterns can be } \\
\text { considered for the development of other digital-based } \\
\text { activities. }\end{array}$ \\
\hline KEYWORDS & $\begin{array}{l}\text { City Logistics, Joint Delivery System, New Normal } \\
\text { Activity, Traditional Market }\end{array}$ \\
\hline (c) (†) (?) & $\begin{array}{l}\text { This work is licensed under a Creative Commons } \\
\text { Attribution-ShareAlike } 4.0 \text { International }\end{array}$ \\
\hline
\end{tabular}




\section{Riza Nuansyah Putra, Ismu Rini Dwi Ari, Christia Meidiana}

\section{INTRODUCTION}

The concept of logistics has actually been known for a long time and began to be used frequently in the 1950s [1]. Logistics can simply be interpreted as the flow of material, information, and money between consumers and suppliers. The development of logistics goes hand in hand with advances in management theory and information systems, which have more influence on business and economics. Urban logistics focuses on the activities of transporting goods, social or environmental problems, congestion, and energy saving in urban areas [2].

In general, the problem of urban logistics is the high cost and time requirements of the movement of goods in urban areas. Electronic commerce offers a solution to this problem which has been proven in several cases. Emkhe shows that electronic commerce can shorten delivery times because it can be done anywhere and anytime [3]. In Indonesia, the E-Commerce Statistical Report notes that 53.52\% of new entrepreneurs, dominated by the wholesale and retail sector, use digital platforms to market their goods [4].

Technological developments have also begun to be applied to conventional trading activities. In addition, the COVID-19 pandemic has also spurred the application of online buying and selling activity programs in line with the enactment of social restrictions [5]. In the 2020-2024 RPJMN, a strategy that can be carried out by the people's market is the development of an information system that utilizes technology to survive in the new normal. The people's market, which is a place for direct meetings between sellers and buyers, has begun to adapt to accepting orders online (in a network).

PERWALI Malang City No. 19 of 2020 Article 24 paragraph 1 point c, contains rules so that people's market managers facilitate and prioritize online buying and selling transactions. As a result, there are ten people's markets in Malang City that serve online transactions during the new normal [6]. Developers of freight forwarding services are divided into two types of providers, namely government and private. The Malang City Government through DISKOPERINDAG uses the Instagram application service (Instagram Pasar Rakyat) and the website (pasar.id) as a medium for ordering. Meanwhile, private developers such as GO-Jek, Grab, and E-Pasar have their own applications according to the characteristics of the service. The difference in media has an impact on the interest of buyers in buying and selling online.

Existing facilities and infrastructure for the Oro-oro Dowo People's Market are in accordance with SNI 8125 2015. However, in order to accommodate the interests of service developers, an appropriate mechanism is needed. Considering the number of service developers, the joint delivery system was chosen as a logistics development concept which involves collaboration. The shared delivery system is a core scheme in city logistics for more efficient and environmentally friendly urban transportation [7]. The goal is to increase the efficiency of urban goods distribution by consolidating goods from competitive freight carriers, reducing environmental damage, reducing congestion, improving safety and security conditions in urban areas [8].

The movement of vehicles to the people's market begins with the arrival of the supply of goods and continues with the visit of buyers directly to the location. Currently, the Oro-oro Dowo People's Market has been facilitated by four developers who are ready to help with the distribution of goods. Drivers number from GO-Jek has reached 10,000. This number has not been updated and added from Grab driver partners, eา-pasar, Instagram pasar rakyat and pasar.id which causes the accumulation of transportation.

Although it has been supported by several online transaction service providers, the Malang City Government needs to consider future conditions. Nowadays service 
providers in the form of category $\mathrm{H}$ (transportation and warehousing) are an urban constraint with the large number of couriers operating. On the other hand, it can be said that e-pasar or pasar.id is not ready to provide couriers for delivery of goods, which is one of the logistics needs. Therefore, a collaboration scheme between stakeholders is needed based on their respective needs. The joint delivery system is a logistics development concept that will be implemented at the Oro-oro Dowo Online Traditional's Market.

This research starts from identifying the movement of goods produced by online transaction service providers. At this stage, a stakeholder interaction model centered on service providers is also described. Furthermore, assessing the influence of the movement on the space requirements of the Oro-oro Dowo Traditional's Market. At this stage, the courier movement of each developer in the market is also described. Finally, the preparation of logistics development recommendations is divided into two, namely market spatial planning and also stakeholder interaction schemes. The benefit of this research is that it can be used as input and consideration for the Government in developing logistics in other sectors in Malang City. Then, it can be a reference for academics in research on urban logistics.

\section{RESEARCH METHOD}

This research on the logistics development of the Oro-oro Dowo Online Traditional's Market in choosing qualitative approach. The question is that qualitative research is more appropriate to use on new phenomena whose problems are still not clear (Sugiono, 2019). In addition, the qualitative approach was chosen on the grounds of the limitations of the discussion of strategy quantitative analysis techniques. The qualitative model chosen is a "case study" which develops an in-depth analysis of a problem, related program, event, activity, process, or one or more individuals.

\section{RESULT AND DISCUSSION}

The pattern of distribution of goods is the pattern of distribution of goods from several online service developers at the Oro-oro Dowo Traditonal's Market which is described through tabulations and pictures. The problem in this identification is that it not easy to get data from application developers. Grab and Go-Jek are only willing to provide data to the Ministry of Land Transportation as the highest organizing agency. In other cases, Instagram Pasar Rakyat does not accommodate orders into a database. It is difficult to know the list of customers who may have made transactions. Finally, in the EPasar application, the difficulty is that the travel data is limited to the destination point where transactions do not occur every day. Therefore, the authors conducted observations and interviews at the research site to obtain data. The results can be seen in the description below accompanied by a picture of the destination location.

Table 1. Delivery Destination in 1 month

\begin{tabular}{ccc}
\hline Provider & Destination & Intensity \\
\hline Instagram Traditional & Tlogomas & Twice a day \\
Market & & \\
& Araya & Twice a day \\
E-Pasar & Ijen & 2 \\
& Bareng & 1 \\
GO-Jek & Veteran & 2 \\
\hline
\end{tabular}




\section{Riza Nuansyah Putra, Ismu Rini Dwi Ari, Christia Meidiana}

\begin{tabular}{ccc} 
& Bareng & 1 \\
\hline Grab & Syaiful Anwar Hospital & 2 \\
\hline
\end{tabular}

Based on interviews with the Pasar Rakyat Instagram courier, it was found that the average buyer was a regular customer of Oro-oro Dowo People's Market before the pandemic. For protocol reasons, most buyers who have middle and upper economic abilities can afford the cost of goods and accommodation. Regular customers of the Pasar Rakyat Instagram application are in Araya Housing and Tlogomas Housing. different from customers from E-Pasar, GO-Jek, and Grab who place an order once without any continuity.

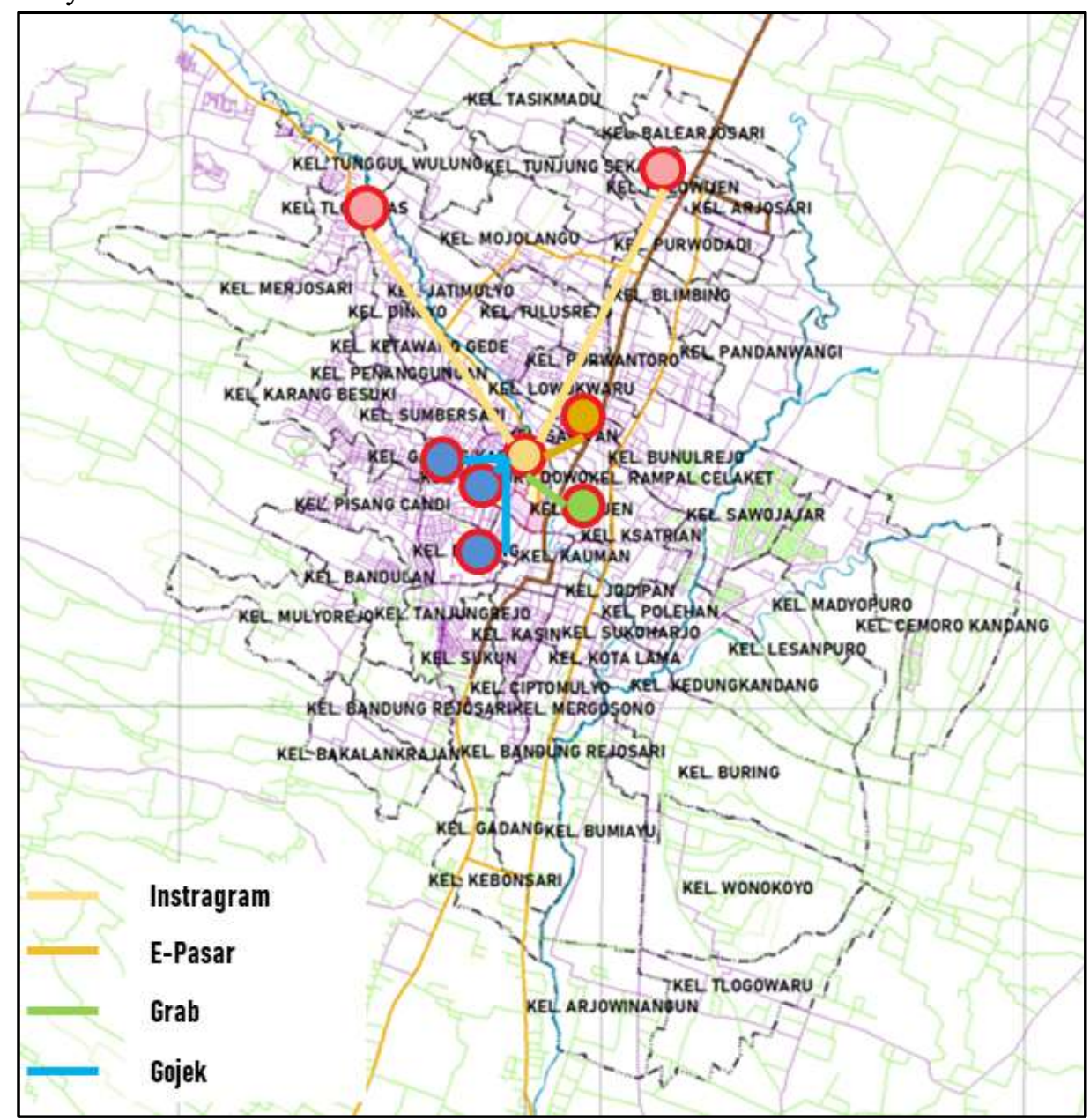

Figure 1. Goods Movement Providers

Tables and Figures are placed in the text group after the table or figure is referenced. Each image must be given an image title below the image and numbered sequentially, followed by the first image. Each table must be given a table title and numbered sequentially at the top of the table. Images must be guaranteed to be printed clearly (size, font, resolution and line size must be sure printed clearly). Figures and tables and diagrams/schematics should be placed in columns between groups of text or if 
they are too large they should be placed in the center of the page. The table must not contain vertical lines. While horizontal stripes are allowed but only essential.

Before entering into stakeholder relations, we will discuss the possible scenarios. Figure 2 explains that there will be a new service zone from online transactions. This means that in the future the Oro-oro Dowo Traditional's Market needs to pay attention to existing orders so that services do not overlap with other markets. In addition, vehicle towing also needs to be considered, considering the current conditions are not as busy as now.

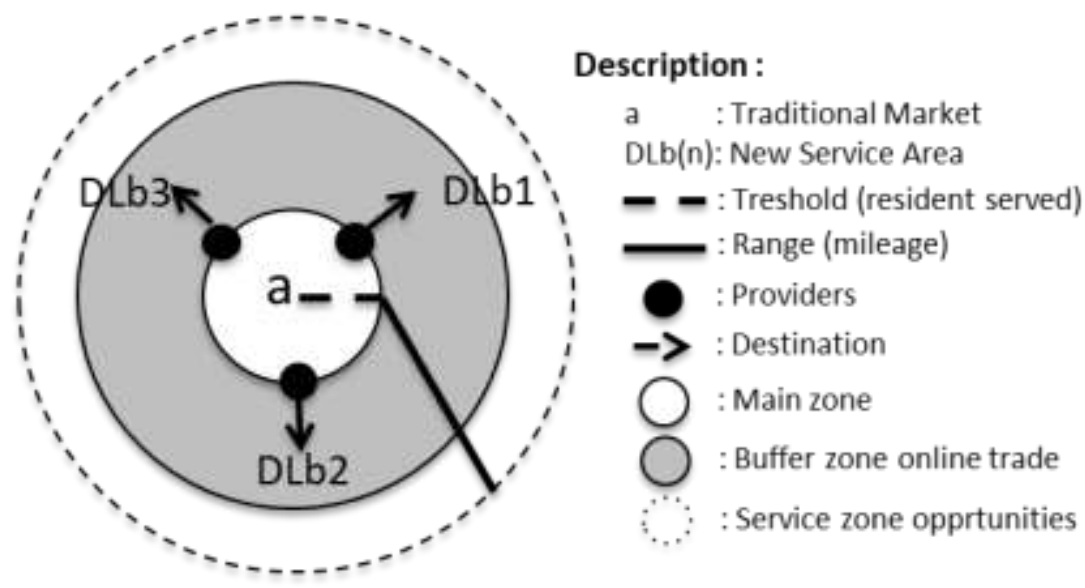

Figure 2. Development Service Area Traditonal Market

The purpose of the joint delivery system is to increase the efficiency of urban goods distribution by consolidating goods from competitive freight carriers as well as reducing environmental damage, reducing congestion, improving safety and security conditions in urban areas (Taniguchi, 2014). Therefore, it is necessary for the Oro-oro Dowo People's Market stakeholder scheme to follow this approach. For more details, see Figure 3 below.

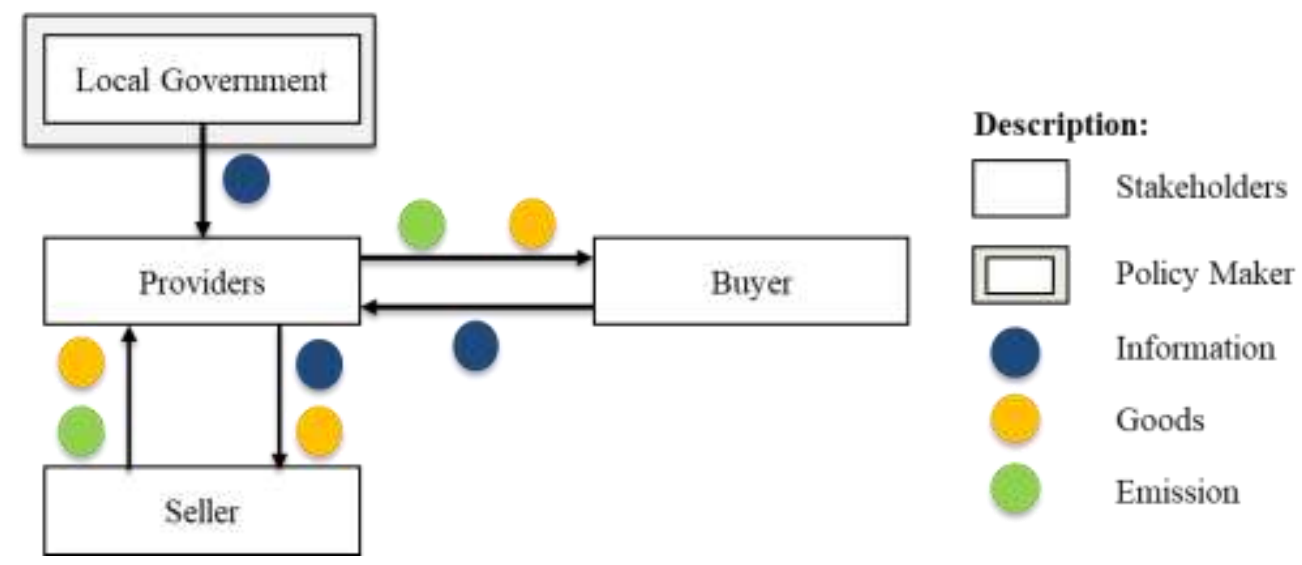

Figure 2. Stakeholders Interaction Recommendation 


\section{Riza Nuansyah Putra, Ismu Rini Dwi Ari, Christia Meidiana}

\section{CONCLUSION}

Technological developments are part of human life following the times. The process of digitizing every aspect of human life can be seen from two sides that need to be considered. From the study of the location, the existence of goods delivery services has a positive impact on traders. Traders can increase transaction intensity without expending additional energy. In addition, in the future it is necessary to improve facilities and infrastructure that support online transaction activities at the Oro-oro Dowo Traditional Market. And lastly, it is necessary to improve the collaboration system between stakeholders. Local governments need to regulate online transaction service providers so as not to cause problems in the future.

\section{REFERENCES}

Frazelle, E. (2002). SUPPLY CHAIN STRATEGY The Logistics of Supply Chain Management McGraw-Hill.

Rushton, A., Croucher, P. and Baker, P. (2014). Handbook of logistics and distribution management

Taniguchi, E., Thompson, R.G., Yamada T., Van Duin, R. (2001). City Logistics. Network Modelleing Intelligent Transport System. The Netherland: Pergamon.

Taniguchi, E., Thompson, R.G., Yamada T., (2015). "Urban Transportation and Logistics: Health, Safety, and Security Concerns (E. Taniguchi, T.F. Fwa, dan R.G. Thompson, Eds)," CRC Press, Taylor \& Francis, Boca Raton, hlm. 1-30.

Widodo, K. H., Parikesit, D., Dewanti, Hadi, M. P., Sa'duddin, Basalim, S., Purwoto, H., Nugroho D. P., Perdana, Y. R. (2019). Logistik Perkotaan di Indonesia. Yogyakarta: UGM Press.

Mardiansjah, F. H., \& Rahayu, P. (2019). Urbanisasi Dan Pertumbuhan Kota-Kota Kawasan Makro Indonesia. https://doi.org/10.14710/jpk.7.1.91-110

Badan Pusat Statistik. (2020). Statistik E-Commerce. 2020. Jakarta: BPS.

Harahap, D. A. (2020). Virus corona dan beralihnya pedagang tradisional ke online. 2019(May), 2019-2020. https://doi.org/10.13140/RG.2.2.15210.13760

Wangapisit, O., Taniguchi, E., Teo, J. S. E., \& Qureshi, A. G. (2014). Multi-agent Systems Modelling for Evaluating Joint Delivery Systems. Procedia - Social and Behavioral Sciences, 125, 472-483.

Arikunto Suharsimi (2016). Research Procedures A Practical Approach. Jakarta: PT Rineka Cipta. 